\title{
PENINGKATAN AKTIVITAS DAN HASIL BELAJAR PENDIDIKAN AGAMA KATOLIK DAN BUDI PEKERTI MELALUI MODEL PEMBELAJARAN DISCOVERY LEARNING
}

\author{
Maria Margaretha Dwilinda \\ SMA Negeri 1 Sedayu \\ dwilinda68@gmail.com
}

\begin{abstract}
Abstrak: Tujuan penelitian ini adalah untuk meningkatkan aktivitas dan hasil belajar pendidikan agama Katolik dan budi pekerti pada kompetensi dasar memahami peran dan fungsi suara hati sehingga dapat bertindak secara benar dan tepat melalui model pembelajaran Discovery Learning. Penelitian ini adalah penelitian tindakan kelas yang melibatkan 10 orang siswa beragama Katolik kelas XI IPS1 SMA Negeri 1 Sedayu pada tahun pelajaran 2019/2020. Tindakan dilakukan dalam dua siklus pembelajaran. Data dikumpulkan dengan pedoman observasi, tes pada masing-masing siklus, dan dianalisis secara deskriptif. Hasil penelitian menunjukkan bahwa pada siklus I rata-rata prosentase aktivitas belajar siswa sebesar 67,50\% dengan ketuntasan klasikal hasil belajar kognitif diperoleh sebesar 60\%, dengan ratarata nilai hasil belajar sebesar 77,5. Pada siklus II rata-rata prosentase aktivitas belajar siswa sebesar 90,63\% dengan ketuntasan klasikal hasil belajar kognitif sebesar 90\%, dengan rata-rata nilai hasil belajar sebesar 83,5. Dengan demikian penerapan penggunaan model pembelajaran Discovery Learning ini dapat meningkatkan aktivitas dan hasil belajar siswa.
\end{abstract}

Kata kunci: aktivitas, hasil belajar, discovery learning

\section{IMPROVING ACTIVITIES AND STUDYING OUTCOMES OF CATHOLIC RELIGIOUS EDUCATION AND CHARACTER BUILDING THROUGH DISCOVERY LEARNING MODEL}

Abstract: The purpose of this study is to improve the activities and studying outcomes of Catholic religious education and character in basic competence for understanding the role and function of conscience so that it can act correctly and appropriately through the Discovery Learning Model. This research is a classroom action research study involving 10 Catholic students of XI IPS1 of SMA Negeri 1 Sedayu in 2019/2020. The action is carried out in two learning cycles. Data were collected using observational guidelines, tests in each cycle, and analyzed descriptively. The results showed that in the first cycle the average percentage of student learning activities amounted to $67.50 \%$ with classical completeness cognitive learning outcomes obtained by 60\%, with an average value of learning outcomes of 77.5. In the second cycle the average percentage of student learning activities amounted to $90.63 \%$ with classical completeness of cognitive learning outcomes of $90 \%$, with an average value of learning outcomes of 83.5. Thus the application of the use of the Discovery Learning Model can improve student learning activities and outcomes.

Keywords: activities, studying outcomes, discovery learning

\section{PENDAHULUAN}

Pelajaran pendidikan agama Katolik dan budi pekerti merupakan rangkaian hasil usaha yang dilakukan secara terencana dan berkesinambungan dalam rangka mengembangkan kemampuan siswa untuk memperteguh iman dan ketaqwaan kepada Tuhan Yang Maha Esa sesuai dengan ajaran iman Katolik. Usaha tersebut dilakukan dengan tetap memperhatikan penghormatan terhadap agama lain demi terciptanya kerukunan antarumat beragama dalam masyarakat untuk mewujudkan persatuan nasional.

Tak jauh berbeda dengan mata pelajaran lain, pendidikan agama Katolik dan budi pekerti menjadi salah satu mata pelajaran di sekolah. Sebagaimana setiap mata pelajaran memiliki tujuannya, demikian juga dengan pendidikan agama Katolik dan budi pekerti bertujuan untuk membantu siswa mengembangkan pengetahuan, keterampilan, dan sikap membangun hidup yang semakin beriman. Pengetahuan dimiliki melalui aktivitas-aktivitas: mengetahui, memahami, menerapkan, menganalisis, dan mengevaluasi. Keterampilan diperoleh melalui aktivitas-aktivitas, antara lain: mengamati, menanya, mencoba, menalar, menyaji, dan mencipta. Sikap dibentuk melalui pembiasaan: menerima, menjalankan, menghargai, menghayati, dan mengamalkan. 
Untuk mencapai tujuan tersebut, pendidikan agama Katolik dan budi pekerti dilaksanakan melalui proses pembelajaran, di mana siswa sebagai pribadi dan pembelajar menjadi sentral yang secara aktif dikondisikan sebagai subyek yang membangun kesadaran dan pembelajarannya sendiri dalam berinteraksi antarsiswa, interaksi dengan pendamping (guru), dan refleksi serta aksi mengikutinya atas kondisi real lingkungan pembelajaran. Siswa didorong, diasuh, dan diasah untuk aktif berkomunikasi, bereksplorasi, terampil berefleksi, dan berani menyatakan sikap dan pendapatnya. Demikian proses belajar mengajar ini dikembangkan dan diharapkan pada akhirnya memperoleh nilai hasil belajar yang maksimal.

Gambaran tentang proses belajar mengajar pendidikan agama Katolik dan budi pekerti di atas, pada kenyataan di lapangan sulit untuk dilaksanakan. Hal ini dikarenakan guru harus menyelesaikan target kurikulum dalam kurun waktu yang telah ditentukan. Selain itu, dengan terbatasnya waktu pembelajaran pendidikan agama Katolik dan budi pekerti yang bertujuan untuk membantu siswa mengembangkan pengetahuan, keterampilan, dan sikap membangun hidup yang semakin beriman tidak mudah diambil penilaian hasil belajarnya, terlebih untuk penilaian keterampilan dan sikapnya.

Umumnya guru pendidikan agama Katolik dan budi pekerti agak mengabaikan penilaian keterampilan dan sikap. Hal ini disebabkan karena sistem ulangan atau ujian yang biasanya menjabarkan soal-soal yang sebagian besar bersifat teoritis (pengetahuan). Dengan ini menimbulkan motivasi guru mengajarkan materi pendidikan agama Katolik dan budi pekerti hanya untuk dapat menjawab soal-soal ulangan atau ujian supaya hasil belajarnya baik. Apalagi ketika materi yang diproseskan dalam pembelajaran adalah kompetensi dasar memahami peran dan fungsi suara hati sehingga dapat bertindak secara benar dan tepat, untuk penilaian pengetahuan bagi guru mudah untuk membuat soal-soalnya. Namun untuk penilaian keterampilan dan sikap terkait dengan kompetensi dasar tersebut sangatlah sulit. Hal ini juga berpengaruh pada aktivitas siswa, ada rasa enggan untuk mengolah hati secara jujur dan benar. Hasil belajar siswa kelas X IPS1 SMA Negeri 1 Sedayu pra penelitian pada kompetensi dasar memahami peran dan fungsi suara hati sehingga dapat bertindak secara benar dan tepat yang memperoleh nilai lebih dari 80 hanya 3 orang siswa dari 10 siswa yang mengikuti tes. Ini berarti yang bahwa pembelajaran pendidikan agama Katolik dan budi pekerti dikatakan kurang berhasil karena hanya 30\% siswa yang tuntas.

Berdasarkan kenyataan di atas dan juga observasi diketahui bahwa faktor penyebab tidak terolahnya seluruh kompetensi siswa dalam pembelajaran pendidikan agama Katolik dan budi pekerti adalah model pembelajaran yang dilaksanakan masih terpusat pada guru. Siswa kurang diarahkan untuk berpikir kreatif dan menguasai konsep berdasarkan penemuan-penemuan di lapangan, selanjutnya mengolah apa yang ditemukannya itu menjadi sikap diri yang perlu dikembangkannya dalam hidupnya sehari-hari. Dengan kata lain, butuh model pembelajaran yang dapat mengarahkan siswa belajar secara aktif, kreatif, dan yang berdampak pada hasil belajar mencapai KKM.

Berdasarkan pada latar belakang yang dipaparkan di atas, beberapa masalah yang dapat diidentifikasi yaitu: 1) aktivitas belajar siswa terhadap pembelajaran pendidikan agama Katolik dan budi pekerti di sekolah masih rendah; 2) pencapaian hasil belajar siswa belum maksimal; dan 3) model pembelajaran Discovery Learning merupakan salah satu upaya meningkatkan aktivitas dan hasil belajar siswa.

Rumusan masalah dalam penelitian tindakan kelas ini dapat dirumuskan: 1) apakah melalui model pembelajaran Discovery Learming keaktifan dan hasil belajar siswa pada mata pelajaran pendidikan agama Katolik dan budi pekerti kelas X IPS1 SMA Negeri 1 Sedayu dapat meningkat?; 2) bagaimana upaya meningkatkan keaktifan dan hasil belajar siswa pada mata pelajaran agama Katolik dan budi pekerti kelas X IPS1 SMA Negeri 1 Sedayu?

Sesuai dengan rumusan masalah sebagaimana dikemukakan di atas, maka tujuan penelitian ini adalah: 1) meningkatkan aktivitas dan hasil belajar siswa pada mata pelajaran pendidikan agama Katolik di kelas X IPS1 SMA Negeri 1 Sedayu dengan menggunakan model pembelajaran Discovery Learning; 2) mendapat informasi tentang penerapan pembelajaran Discovery Learning merupakan upaya meningkatkan aktivitas dan 
hasil belajar siswa pada mata pelajaran pendidikan agama Katolik dan budi pekerti di kelas X IPS1 SMA Negeri 1 Sedayu.

Hasil penelitian ini diharapkan dapat memberikan kegunaan sebagai berikut: 1) bagi siswa: (a) meningkatkan aktivitas siswa dalam pembelajaran pendidikan agama Katolik dan budi pekerti; (b) meningkatkan hasil belajar; 2) bagi pendidik: supaya proses pembelajaran siswa lebih aktif dan kreatif dalam menggunakan berbagai model pembelajaran, sehingga pembelajaran lebih menarik dan menyenangkan terutama pada materi yang menuntut pengolahan seluruh kompetensi (sikap, pengetahuan, dan keterampilan); 3) bagi sekolah: (a) meningkatkan hasil belajar sekolah terutama pada mata pelajaran pendidikan agama Katolik dan budi pekerti; (b) meningkatkan kinerja sekolah melalui peningkatan profesionalitas guru.

\section{METODE PENELITIAN \\ Jenis Penelitian}

Penelitian ini menggunakan pendekat-an deskriptif kuantitatif yaitu penelitian yang dilakukan untuk mengetahui nilai variabel mandiri, baik satu variabel atau lebih (independen) tanpa membuat perbandingan, atau menghubungkan dengan variabel lain.

\section{Waktu dan Tempat Penelitian}

Penelitian dilakukan selama 4 (empat) bulan, yaitu dari bulan September 2019 s.d Desember tahun 2019, dengan tempat penelitian SMA Negeri 1 Sedayu.

\section{Subjek Penelitian}

Subjek dalam penelitian ini adalah siswa kelas X IPS1 SMA Negeri 1 Sedayu tahun pelajaran 2019/2020, dengan jumlah siswanya 10 orang siswa terdiri dari 4 orang siswa lakilaki dan 6 orang siswa perempuan. Siswa kelas ini dipilih sebagai subjek penelitian karena keaktifan siswanya yang masih kurang dan memiliki hasil belajar yang rendah. Hal ini terlihat dari banyaknya siswa yang belum mencapai KKM di mata pelajaran pendidikan agama Katolik dan b udi pekerti sebesar 80 .

\section{Prosedur}

Penelitian ini dilakukan dengan menggunakan metode penelitian tindakan kelas mengadaptasi pendapat yang dikembangkan oleh Kemmis dan Mc. Taggart. Dalam model ini, penelitian tindakan terdiri dari 4 tahap yaitu perencanaan (planning), pelaksanaan (acting), pengamatan (observing), dan refleksi (reflecting) yang dapat digambarkan sebagai berikut:

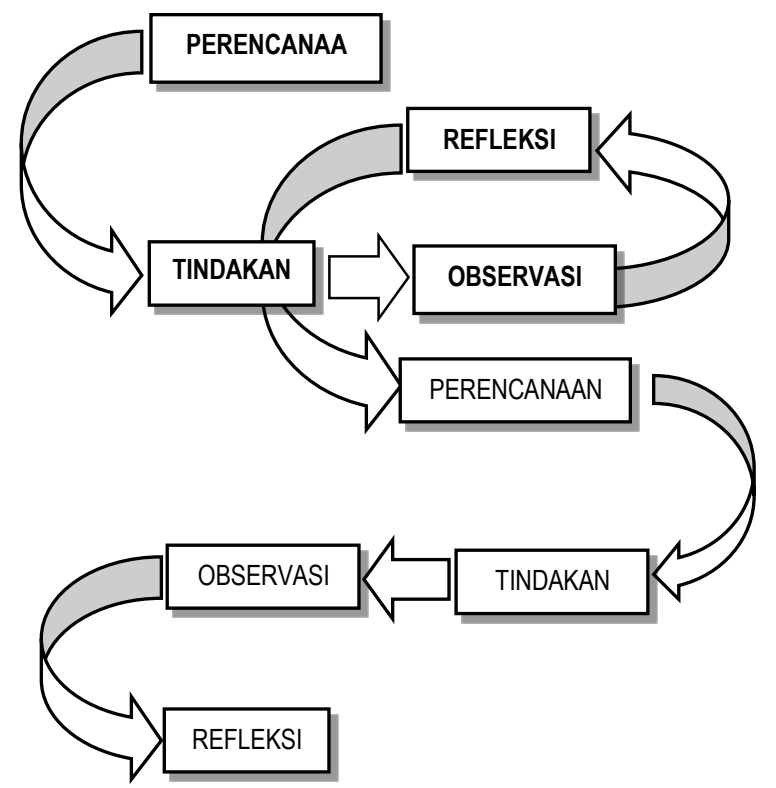

Gambar 1. Tahapan Penelitian Tindakan Kelas

\section{Siklus I}

1. Perencanaan (Planning)

a. Guru menentukan materi pembelajaran yang akan diajarkan.

b. Guru menyusun rencana pelaksanaan pembelajaran (RPP).

c. Guru membentuk siswa menjadi beberapa kelompok.

d. Guru membuat lembar observasi kegiatan dan keaktifan siswa dan guru.

e. Guru membuat soal ujian siklus I .

2. Pelaksanaan (Acting)

a. Guru mengkondisikan siswa untuk belajar aktif, misalnya berdoa, mengabsen, dan mempersiapkan alat tulis.

b. Guru menyampaikan tujuan pembelajaran, motivasi.

c. Guru memberikan pertanyaan yang menuntun siswa masuk kedalam permasalahan pembelajaran.

d. Guru memberikan kesempatan kepada siswa mengidentifikasi masalah yang relevan dengan bahan pelajaran.

e. Guru membimbing siswa dalam proses pengidentifikasian masalah.

f. Guru menugaskan siswa untuk mengumpulkan informasi dari berbagai sumber yang relevan dengan bahan pelajaran.

g. Guru membimbing siswa secara aktif menemukan sesuatu yang berhubungan dengan permasalahan yang dihadapi. 
h. Guru memberikan kesempatan pada siswa untuk mengolah dan mengklarifikasikan informasi yang telah diperolehnya.

i. Guru membimbing kegiatan mengolah data dan informasi yang telah diperoleh siswa.

j. Guru memberikan kesempatan pada siswa untuk menemukan suatu konsep, teori, aturan atau pemahaman melalui contoh-contoh yang dijumpainya dalam kehidupan sehari-hari.

k. Guru membimbing siswa agar dapat berdiskusi dan membuktikan jawaban permasalahan.

1. Guru membimbing siswa untuk meninjau ulang hasil pengumpulan dan pengolahan data dengan data atau teori pada buku sumber atau literatur lain yang berkaitan dengan materi pem-belajaran.

m.Guru membantu siswa menarik kesimpulan berdasarkan data yang telah didapat dan dianalisis bersama dan meluruskan apabila terjadi miskonsepsi.

n. Guru memberi tugas tindak lanjut dan melakukan evaluasi.

\section{Pengamatan (Observing)}

a. Pengamatan terhadap siswa

1) Kesiapan siswa untuk belajar aktif.

2) Kemauan siswa untuk mendengarkan informasi atau penjelasan dari guru.

3) Keaktifan siswa dalam menjawab pertanyaan yang diberikan oleh guru sebagai stimulus untuk masuk kedalam permasalahan dalam pembelajaran.

4) Partisipasi siswa dalam kelompok untuk mengidentifikasi masalah yang relevan dengan bahan pelajaran.

5) Keaktifan siswa dalam berdiskusi tentang proses peng-identifikasian masalah yang diperoleh.

6) Tanggung jawab siswa dalam mengumpulkan informasi dari berbagai sumber yang relevan dengan bahan pelajaran.

7) Keaktifan siswa dalam me-nemukan sesuatu yang berhubungan dengan permasalahan yang dihadapi, terkait dengan bahan pelajaran.

8) Partisipasi siswa dalam mengolah dan mengklasifikasikan informasi yang telah diperolehnya.
9) Tanggung jawab siswa dalam mengolah data dan informasi yang telah diperolehnya.

10) Tanggung jawab siswa untuk membuktikan penemuan suatu konsep, teori, aturan atau pemahaman melalui contoh-contoh yang di-jumpainya dalam kehidupan sehari-hari.

11) Partisipasi siswa dalam berdiskusi dan membuktikan jawaban permasalahan berdasarkan dari apa yang dibacanya.

12) Keaktifan siswa untuk meninjau ulang hasil pengumpulan dan pengolahan data dengan data atau teori pada buku sumber atau literatur lain yang berkaitan dengan materi.

13) Keaktifan siswa dalam me-narik kesimpulan berdasarkan data yang telah didapat dan dianalisis bersama.

14) Keaktifan dan tanggung jawab siswa dalam mengerjakan evaluasi atau tes yang dihadapinya.

15) Kesesuaian jawaban dengan materi yang dibahas.

b. Pengamatan terhadap guru

1) Kehadiran guru.

2) Penampilan guru di muka kelas.

3) Cara guru dalam menyampaikan materi.

4) Cara guru dalam membimbing jalannya proses pembelajaran dengan menggunakan model pembelajaran discovery learning.

5) Pengelolaan waktu.

6) Pengelolaan kelas.

\section{Refleksi (Reflecting)}

Refleksi tindakan kelas siklus I dengan menganalisis data kuantitatif dan kualitatif yang digunakan. Jika analisis data kuantitatif menunjukkan aktivitas dan hasil belajar siswa masih dalam kategori baik dan pencapaian kognitif kurang dari $75 \%$ belum terpenuhi, maka perlu diulang kembali untuk memperbaiki kelemahan-kelemahan pada siklus I agar mencapai keaktifan siswa dalam kategori baik dan ketuntasan belajarnya lebih dari $75 \%$ pada siklus berikutnya. Langkah-langkah pada siklus II prinsipnya sama dengan siklus I. 


\section{Siklus II}

1. Perencanaan (Planning)

a. Guru menentukan pokok bahasan yang diajarkan.

b. Guru menyusun rencana pelaksanaan pembelajaran.

c. Guru membentuk kelompok yang terdiri 2-3 orang siswa yang heterogen.

d. Guru membuat wacana untuk beberapa kelompok.

e. Guru membuat lembar observasi kegiatan dan keaktifan siswa dan guru dalam penerapan model pem-belajaran Discovery Learning

f. Guru membuat soal ujian siklus II.

2. Pelaksanaan (Acting)

a. Guru mengkondisikan siswa untuk belajar aktif, misalnya berdoa, mengabsen, dan mempersiapkan alat tulis.

b. Guru menyampaikan tujuan pembelajaran, motivasi.

c. Guru memberikan pertanyaan yang menuntun siswa masuk kedalam permasalahan pembelajaran.

d. Guru memberikan kesempatan kepada siswa mengidentifikasi masalah yang relevan dengan bahan pelajaran.

e. Guru membimbing peserta dalam proses pengidentifikasian masalah.

f. Guru menugaskan siswa untuk mengumpulkan informasi dari berbagai sumber yang relevan dengan bahan pelajaran.

g. Guru membimbing siswa secara aktif menemukan sesuatu yang ber-hubungan dengan permasalahan yang dihadapi.

h. Guru memberikan kesempatan pada siswa untuk mengolah dan mengklarifikasikan informasi yang telah diperolehnya.

i. Guru membimbing kegiatan mengolah data dan informasi yang telah diperoleh siswa.

j. Guru memberikan kesempatan pada siswa untuk menemukan suatu konsep, teori, aturan atau pemahaman melalui contoh-contoh yang dijumpainya dalam kehidupan sehari-hari.

k. Guru membimbing siswa agar dapat berdiskusi dan membuktikan jawaban permasalahan.

1. Guru membimbing siswa untuk meninjau ulang hasil pengumpulan dan pengolahan data dengan data atau teori pada buku sumber atau literatur lain yang berkaitan dengan materi pem-belajaran.

m.Guru membantu siswa menarik kesimpulan berdasarkan data yang telah didapat dan dianalisis bersama dan meluruskan apabila terjadi miskonsepsi.

n. Guru memberi tugas tindak lanjut dan melakukan evaluasi.

3. Pengamatan (Observing)

a. Pengamatan terhadap siswa

1) Kesiapan siswa untuk belajar aktif.

2) Kemauan siswa untuk mendengarkan informasi atau penjelasan dari guru.

3) Keaktifan siswa dalam men-jawab pertanyaan yang diberikan oleh guru sebagai stimulus untuk masuk kedalam permasalahan dalam pembelajaran.

4) Partisipasi siswa dalam kelompok untuk mengidentifikasi masalah yang relevan dengan bahan pelajaran.

5) Keaktifan siswa dalam berdiskusi tentang proses pengidentifikasian masalah yang diperoleh.

6) Tanggung jawab siswa dalam mengumpulkan informasi dari berbagai sumber yang relevan dengan bahan pelajaran.

7) Keaktifan siswa dalam menemukan sesuatu yang berhubungan dengan permasalahan yang dihadapi, terkait dengan bahan pelajaran.

8) Partisipasi siswa dalam mengolah dan mengklasifikasikan informasi yang telah diperolehnya.

9) Tanggung jawab siswa dalam mengolah data dan informasi yang telah diperolehnya.

10) Tanggung jawab siswa untuk membuktikan penemuan suatu konsep, teori, aturan atau pemahaman melalui contoh-contoh yang dijumpainya dalam kehidupan sehari-hari.

11) Partisipasi siswa dalam berdiskusi dan membuktikan jawaban permasalahan berdasarkan dari apa yang dibacanya.

12) Keaktifan siswa untuk meninjau ulang hasil pengumpulan dan pengolahan data dengan data atau teori pada buku sumber atau literatur lain yang berkaitan dengan materi. 
13) Keaktifan siswa dalam menarik kesimpulan berdasarkan data yang telah didapat dan dianalisis bersama.

14) Keaktifan dan tanggung jawab siswa dalam mengerjakan evaluasi atau tes yang dihadapinya.

15) Kesesuaian jawaban dengan materi yang dibahas.

b. Pengamatan terhadap guru

1) Kehadiran guru.

2) Penampilan guru di muka kelas.

3) Cara guru dalam menyampaikan materi.

4) Cara guru dalam membimbing jalannya proses pembelajaran dengan menggunakan model pembelajaran discovery learning.

5) Pengelolaan waktu.

6) Pengelolaan kelas.

4. Refleksi (Reflecting)

Refleksi tindakan kelas siklus II dilakukan setelah pelaksanaan tindakan siklus II selesai dilakukan. Siklus II dihentikan jika dipandang sudah lebih baik dan semua indikator pembelajaran sudah dapat dikuasai oleh siswa. Hal ini dapat dilihat dari aktivitas belajar siswa yang sudah dalam kategori sangat baik dan hasil tes evaluasi siklus II yang diperoleh siswa lebih baik atau mengalami peningkatan dibandingkan dengan siklus I, yaitu sebesar $85 \%$. Oleh karena itu, maka tindakan kelas cukup sampai pada siklus II.

Data, Intrumen, dan Teknik Pengumpulan Data

Data pendukung penelitian ini adalah nama siswa yang menjadi subjek penelitian, hasil belajar siswa dari pra penelitian sampai pada siklus II, observasi langsung terhadap subjek yang diteliti selama kegiatan proses belajar mengajar berlangsung untuk melihat keaktifan siswa dalam mengikuti kegiatan tersebut, dan soal evaluasi dalam bentuk pilihan ganda yang diberikan pada siswa di akhir pembelajaran/siklus mulai dari pra penelitian sampai siklus II dengan KKM yang telah ditetapkan, yaitu 80. Dan yang tak kalah penting dari penelitian ini, yang digunakan sebagai pedoman guru dalam melaksanakan pembelajaran adalah Rencana Pelaksanaan Pembelajaran (RPP).

Data tersebut diatas, diisi, dicatat, dikumpulkan, diolah, dan dianalisis dengan teliti dan cermat untuk mendapatkan deskripsi kuantitatif yang akurat.

\section{Teknik Analisis Data}

1. Aktivitas Siswa

Untuk menilai aktivitas siswa dalam pembelajaran menggunakan model pembelajaran Discovery Learning dapat dihitung dengan rumus sebagai berikut:

$$
\text { Nilai }=\frac{\sum \text { skor perolehan }}{\sum \text { skor maksimal }} \times 100 \%
$$

2. Menilai Tes Evaluasi

Untuk menganalisis prosentase keberhasilan siswa setelah proses belajar mengajar setiap siklus dilakukan dengan cara memberikan evaluasi berupa soal tes tertulis dalam bentuk pilihan ganda pada setiap akhir siklus dengan rumus sederhana, sebagai berikut:

$$
\bar{X}=\frac{\sum x}{N}
$$

3. Ketuntasan Belajar

Perhitungan tingkat ketuntasan belajar siswa secara klasikal dapat dihitung dengan statistika sederhana sebagai berikut:

$$
\%=\frac{n}{\mathrm{~N}} \times 100 \%
$$

Penelitian tindakan kelas ini dinyata-kan berhasil jika:

1. Aktivitas kelas dapat tercapai minimal sebesar $75 \%$ dan termasuk dalam klasifikasi kategori baik setelah ditetapkan-nya model pembelajaran Discovery Learning.

2. Nilai individu tiap siswa dan nilai ratarata klasikal mencapai KKM yang telah ditetapkan yaitu minimal 80 dan secara klasikal mencapai minimal $75 \%$ dari seluruh siswa.

\section{HASIL DAN PEMBAHASAN}

Menurut Joyce (dalam Trianto, 2007:5), model pembelajaran adalah suatu perencanaan atau suatu pola yang digunakan sebagi pedoman dalam merencanakan pem-belajaran dikelas atau pembelajaran dalam tutorial dan untuk menentukan perangkat-perangkat pembelajaran termasuk di dalam-nya bukubuku, film dokumenter, kurikulum dan lainlain. Selanjutnya, Joyce (dalam Trianto, 2007:5) menyatakan bahwa setiap model pembelajaran mengarahkan kita ke dalam mendesain pembelajaran untuk mem-bantu siswa sedemikian rupa sehingga tujuan 
pembelajaran tercapai. Terkadang dalam pembelajaran terjadi kegagalan komunikasi. Artinya materi pelajaran atau pesan yang disampaikan guru tidak dapat diterima oleh siswa dengan optimal (Sanjaya, 2011:162). Untuk itu agar pesan atau materi yang disampaikan oleh guru dapat diterima siswa dengan baik maka guru harus dapat menyusun strategi pembelajaran dengan memanfaatkan model pembelajaran, salah satunya dengan model pembelajaran Discovery Learning.

Inti dari model pembelajaran Discovery Learning adalah memberikan kesempatan kepada siswa untuk menyingkap atau mencari tahu tentang suatu permasalahan atau sesuatu yang sebenarnya ada namun belum mengemuka dan menemukan solusinya berdasarkan hasil pengolahan informasi yang dicari dan dikumpulkannya sendiri, sehingga siswa memiliki pengetahuan baru yang dapat digunakannya dalam memecahkan persoalan yang relevan dalam kehidupan sehari-hari. Hal ini berarti dalam model pembelajaran Discovery Learning guru berperan sebagai pembimbing dengan memberikan kesempatan kepada siswa untuk belajar secara aktif, sebagaimana pendapat guru harus dapat membimbing dan meng-arahkan kegiatan belajar siswa sesuai dengan tujuan (Sardiman, 2005:145). Dengan adanya penerapan model pembelajaran Discovery Learning yang diterapkan pada materi ajar memungkinkan siswa untuk belajar yang lebih mandiri. Bruner mengatakan bahwa proses belajar akan berjalan dengan baik dan kreatif jika guru memberikan kesempatan kepada siswa untuk menemukan suatu konsep, teori, aturan, atau pemahaman melalui contoh-contoh yang ia jumpai dalam kehidupannya (Budiningsih, 2005:41). Melalui kegiatan tersebut siswa akan menguasainya, menerapkan, serta menemukan hal-hal yang bermanfaat bagi dirinya. Model pembelajaran Discovery Learning menjadikan siswa lebih bersemangat dalam belajar, lebih mempersiapkan mental intelektual siswa dalam memecahkan berbagai persoalan yang dihadapi, sehingga menemukan suatu konsep yang dapat diterapkan di lapangan, suasana belajar nyaman, siswa lebih dapat memahami materi pelajaran, siswa lebih berani mengemukakan pendapat dan membuat siswa lebih aktif. Penelitian yang dilakukan merupakan hasil kolaborasi antara obeserver dengan guru mata pelajaran pendidikan agama katolik dan budi pekerti. Tindakan kelas dilakukan dengan tahapan observasi terlebih dahulu, kemudian menyusun rencana tindakan dilanjutkan dengan pelaksanaan tindakan kelas. Hasil penelitian dianalisis untuk mengetahui kelebihan dan kekurangan dalam pembelajaran sehingga dapat menjadi acuan pembelajaran selanjutnya agar menjadi lebih baik.

Berdasarkan data yang diperoleh sebelum pelaksanaan tindakan baik siklus I maupun siklus II diperoleh bahwa terdapat 7 siswa atau $70 \%$ berada dibawah nilai 80 yang berarti tidak tuntas. Setelah dilaksanakan tindakan penelitian dapat diketahui bahwa penggunaan model pem-belajaran Discovery Learning dapat meningkatkan hasil belajar siswa. Hal ini dapat diketahui dari hasil penelitian dari masing-masing siklus. Pada siklus I yang telah dilaksanakan diperoleh data bahwa hasil belajar siswa dengan menggunakan model pembelajaran Discovery Learning yang tuntas adalah 6 anak, sedangkan siswa yang tidak tuntas adalah 4 anak. Diper-oleh skor tertinggi yaitu 85 , skor terendah yaitu 65 , rata-rata nilai 77,5 , dan prosentase ketuntasan belajar klasikal 60\%. Data hasil belajar siswa siklus I dapat dilihat pada Tabel 1.

Tabel 1. Data Hasil Belajar Siswa Siklus I

\begin{tabular}{clc}
\hline No. & \multicolumn{1}{c}{ Hasil Tes } & Siklus I \\
\hline 1. & Nilai Tertinggi & 85 \\
2. & Nilai Terendah & 65 \\
3. & Rata-rata Nilaai & 77,5 \\
4. & Jumlah Siswa yang Tuntas & 6 \\
5. & Jumlah Siswa yang Tidak Tuntas & 4 \\
6. & Prosentase Ketuntasan Belajar Klasikal & $60 \%$ \\
\hline
\end{tabular}

Menurut Mulyasa (2009:254) standar pencapaian ketuntasan belajar sekurangkurangnya $85 \%$ dari keseluruhan. Hasil belajar pada siklus I belum maksimal, maka diputuskan untuk mengadakan siklus II, karena pada siklus I hasil yang diperoleh belum memenuhi standar yang telah ditentukan. Pada siklus II, melalui penerapan model pembelajaran Discovery Learning semakin meningkat yang dapat dilihat dari hasil belajar siswa yang tuntas ada 9 anak, yang tidak tuntas 1 anak. Diperoleh skor tertinggi yaitu 90 , skor terendah yaitu 75 , ratarata nilai 83,5 , prosentase ketuntasan belajar klasikal 90\%. Data hasil belajar siswa siklus II dapat dilihat pada Tabel 2. 
Tabel 2. Data Hasil Belajar Siswa Siklus II

\begin{tabular}{clc}
\hline No. & \multicolumn{1}{c}{ Hasil Tes } & Siklus II \\
\hline 1. & Nilai Tertinggi & 90 \\
2. & Nilai Terendah & 75 \\
3. & Rata-rata Nilaai & 83,5 \\
4. & Jumlah Siswa yang Tuntas & 9 \\
5. & Jumlah Siswa yang Tidak Tuntas & 1 \\
6. & Prosentase Ketuntasan Belajar Klasikal & $90 \%$ \\
\hline
\end{tabular}

Dari data hasil belajar siswa di atas, menunjukkan bahwa ada peningkatan yang signifikan untuk hasil belajar siswa melalui penerapan model pembelajaran Discovery Learning dari siklus I ke siklus II. Ini karena semangat yang tinggi dan perhatian dalam pembelajaran maka hasil yang dicapai menjadi baik dan pembelajaran dikatakan berhasil, karena 85\% siswa sudah mencapai standar ketuntasan belajar minimal yaitu $\geq 80$.

\section{Grafik Hasil Belajar Siswa}

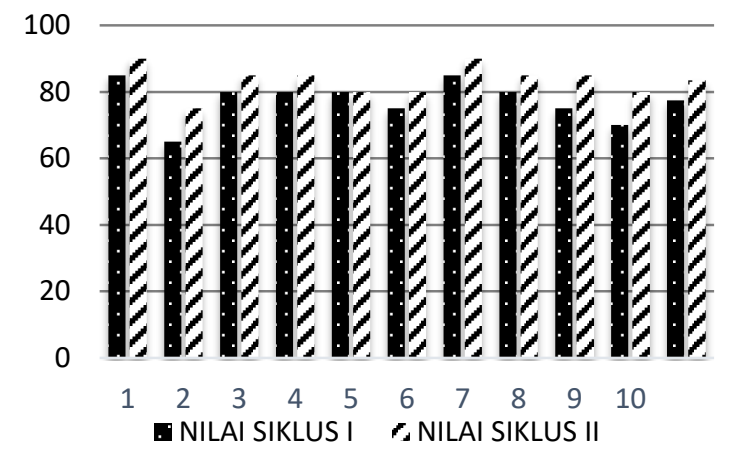

\section{Gambar 2. Grafik Hasil Belajar Siswa}

Peningkatan hasil belajar siswa melalui penerapan model pembelajaran Discovery Learning dari siklus I ke siklus II ini juga berdampak pada aktivitas belajar siswa. Sebelum dilaksanakan penerap-an model pembelajaran Discovery Learning secara intensif dan penuh dengan keseriusan, siswa pasif sehingga pembelajaran menjadi teacher oriented meski di rencana pelaksanaan pembelajaran sudah mengguna-kan model tersebut. Hal ini menumbuhkan kesadaran bahwa jika model yang telah dipilih dalam rencana pelaksanaan pem-belajaran hanya sebatas pada formalitas saja, tanpa diterapkan dalam pelaksanaan selama-nya pembelajaran tidak akan berubah menjadi student oriented. Dari sinilah diputuskan untuk menggunakan model pembelajaran yang telah ditetapkan secara serius dan intensif.

Berdasarkan hasil perhitungan aktivitas belajar siswa pada pelaksanaan pembelajaran siklus I dengan menggunakan model pembelajaran Discovery Learning diperoleh prosentase sebesar $67,50 \%$, nilai tersebut dalam kategori baik. Hal ini dapat diketahui dari suasana pembelajaran yang cukup kondusif meskipun masih terdapat siswa yang kurang memiliki kesiapan untuk belajar aktif, cukup antusias dalam menjawab pertanyaan dari guru sebagai stimulus, tetapi masih ada yang belum terlibat dalam berdiskusi. Siswa aktif dalam mengumpulkan informasi dari berbagai sumber yang relevan, namun ketika harus berdiskusi dan membuktikan jawaban berdasarkan dari apa yang dibacanya serta meninjau ulang hasil pengumpulan dan pengolahan data dengan data atau teori pada buku sumber atau literatur lain yang berkaitan dengan materi pembelajaran kurang ada keberanian. Kondisi ini dikarenakan siswa belum paham tentang model pem-belajaran Discovery Learning, perlu penjelas-an agar memahami model pembelajaran yang digunakan dalam proses kegiatan belajar mengajar. Dengan prosentase aktivitas belajar siswa tersebut di atas, maka diputuskan untuk mengadakan siklus II.

Pada siklus II aktivitas belajar siswa diperoleh prosentase 90,63\%, nilai tersebut dalam kategori sangat baik. Ini berarti aktivitas belajar siswa dengan diterapkan model pembelajaran Discovery Learning ada peningkatan sebesar $23,13 \%$. Peningkatan ini dikarenakan siswa telah paham tentang model pembelajaran Discovery Learning. Dengan demikian berarti dapat disimpulkan bahwa model pembelajaran Discovery Learning dapat meningkatkan aktivitas belajar siswa. Data rekapitulasi pengamatan aktivitas siswa siklus I dan siklus II dapat dilihat pada tabel 3. 
Tabel 3. Rekapitulasi Pengamatan Aktivitas Siswa pada Siklus I dan Siklus II

\begin{tabular}{|c|c|c|c|c|c|}
\hline \multirow{2}{*}{ No } & \multirow{2}{*}{ Indikator } & \multicolumn{2}{|c|}{ Siklus 1} & \multicolumn{2}{|c|}{ Siklus 2} \\
\hline & & $\%$ & Kategori & $\%$ & Kategori \\
\hline & Siswa siap belajar aktif & $70 \%$ & Baik & $80 \%$ & Baik \\
\hline 2. & Siswa mendengarkan informasi tujuan pembelajaran, motivasi & $100 \%$ & Sangat Baik & $90 \%$ & Sangat Baik \\
\hline 3. & $\begin{array}{l}\text { Siswa menjawab pertanyaan dari guru sebagai stimulus untuk } \\
\text { masuk ke dalam permasalahan dalam pembelajaran }\end{array}$ & $60 \%$ & Cukup & $90 \%$ & Sangat Baik \\
\hline 4. & $\begin{array}{l}\text { Siswa masuk dalam kelompok untuk meng-identifikasi masalah } \\
\text { yang relevan dengan bahan pelajaran }\end{array}$ & $100 \%$ & Sangat Baik & $90 \%$ & Sangat Baik \\
\hline 5. & Siswa mendiskusikan proses identifikasi masalah yang diperoleh & $30 \%$ & Cukup & $80 \%$ & Baik \\
\hline & $\begin{array}{l}\text { Siswa mengumpulkan informasi dari berbagai sumber yang } \\
\text { relevan dengan bahan pelajaran }\end{array}$ & $80 \%$ & Baik & $90 \%$ & Sangat Baik \\
\hline 7. & $\begin{array}{l}\text { Siswa belajar secara aktif menemukan sesuatu yang berhubungan } \\
\text { dengan permasalahan yang dihadapi }\end{array}$ & $50 \%$ & & $90 \%$ & Sangat Baik \\
\hline & $\begin{array}{l}\text { Siswa menggunakan kesempatan untuk meng-olah dan } \\
\text { mengklasifikasikan informasi yang telah diperolehnya }\end{array}$ & $60 \%$ & & $90 \%$ & Sangat Baik \\
\hline 9. & Siswa mengolah data dan informasi yang telah diperoleh siswa & $60 \%$ & Cukup & $90 \%$ & Sangat Baik \\
\hline & $\begin{array}{l}\text { Siswa membuktikan penemuan suatu konsep, teori, aturan/ } \\
\text { pemahaman melalui contoh-contoh dalam kehidupan sehari-hari }\end{array}$ & $50 \%$ & Cukup & $100 \%$ & Sangat Baik \\
\hline & $\begin{array}{l}\text { Siswa berdiskusi dan membuktikan jawaban per-masalahan } \\
\text { berdasarkan dari apa yang dibacanya }\end{array}$ & $20 \%$ & Cukup & $100 \%$ & Sangat Baik \\
\hline & $\begin{array}{l}\text { Siswa meninjau ulang hasil pengumpulan dan pengolahan data } \\
\text { dengan data/ teori pada buku sumber/ literatur lain yang berkaitan }\end{array}$ & $40 \%$ & Cukup & $100 \%$ & Sangat Baik \\
\hline & $\begin{array}{l}\text { Siswa menarik kesimpulan berdasarkan data yang telah didapat } \\
\text { dan dianalisis bersama }\end{array}$ & $70 \%$ & Baik & $80 \%$ & Baik \\
\hline 14. & Siswa mengerjakan evaluasi & $100 \%$ & Sangat Baik & $100 \%$ & Sangat Baik \\
\hline & $\begin{array}{l}\text { Siswa melaksanakan tindak lanjut yang diberikan oleh guru } \\
\text { dengan mengerjakan PR }\end{array}$ & $90 \%$ & Sangat Baik & $80 \%$ & Baik \\
\hline & Siswa berdoa dan menjawab ucapan salam. & $100 \%$ & Sangat Baik & $100 \%$ & Sangat Baik \\
\hline & Rerata & $67,50 \%$ & Baik & $90,63 \%$ & Sangat Baik \\
\hline
\end{tabular}

Pelaksanaan model pembelajaran Discovery Learning sudah berjalan sesuai yang diharapkan, siswa mengikuti pelajaran dengan aktif, siswa juga terlihat melaksana-kan tahapan/langkah-langkah pembelajaran Discovery Learning dengan antusias dan semangat, bahkan saat memasuki tahapan/ langkah verification dan generalization siswa dalam kelompok terlihat asyik dan ber-semangat melakukan-nya. Berdasarkan hasil yang telah dicapai selama pelaksanaan pem-belajaran dengan menggunakan model pem-belajaran Discovery Learning, hasil belajar dan aktivitas belajar siswa mengalami peningkatan, maka siklus II dihentikan. Mulai dari sebelum tindakan kelas dilakukan (pra siklus) hingga siklus II terjadi peningkatan aktivitas belajar dan hasil belajar. Keberhasilan penggunaan model pembelajaran Discovery Learning dalam meningkatkan aktivitas siswa dan meningkatkan hasil belajar siswa merupakan indikasi bahwa model pembelajaran Discovery Learning sangat tepat digunakan dalam proses pem-belajaran. Hal ini dapat disimpulkan bahwa penelitian ini sesuai dengan teori yaitu penggunaan model pembelajaran Discovery Learning dapat meningkatkan aktivitas dan hasil belajar siswa.

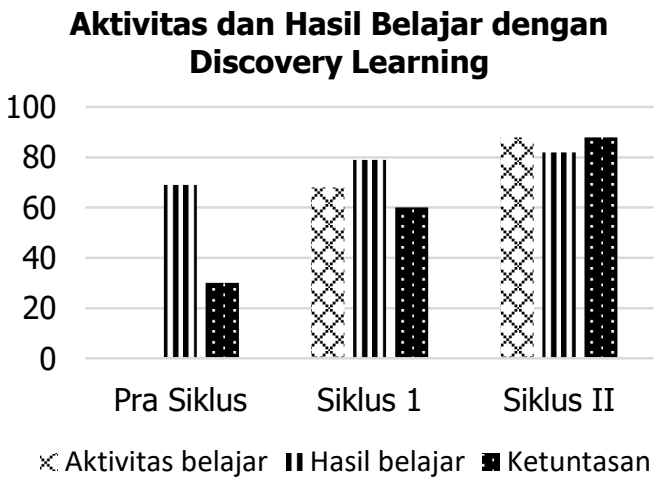

Gambar 3. Aktivitas dan Hasil Belajar Siswa dengan Discovery Learning 


\section{SIMPULAN}

Berdasarkan hasil penelitian dapat disimpulkan bahwa:

1. Penggunaan model pembelajaran Discovery Learning dapat meningkatkan aktivitas dan hasil belajar pendidikan agama katolik dan budi pekerti kelas X IPS1 di SMA Negeri 1 Sedayu pada tahun pelajaran 2019/2020. Hasil peningkatan aktivitas belajar dapat dilihat dari masing-masing siklus yaitu pada siklus I presentase aktivitas belajar peserta didik sebesar $67,50 \%$ dalam kategori baik sedangkan pada siklus II naik menjadi 90,63\% dalam kategori sangat baik. Hasil belajar peserta didik yang diperoleh juga meningkat. Hal ini dapat dilihat dari nilai tes evaluasi dari masing-masing siklus yaitu pada siklus I nilai rata-rata pesert didik sebesar 77,5 sedangkan pada siklus II naik menjadi 83,5. Ketuntasan klasikal pada siklus I sebesar $60 \%$ dan pada siklus II mengalami kenaikan menjadi $90 \%$.

2. Penerapan model pembelajaran Discovery Learning untuk meningkatkan aktivitas dan hasil belajar peserta didik dilakukan dengan cara/langkah, yaitu stimulation (pemberian rangsangan), problem state-ment (pernyataan/ identifikasi masalah), data collection (pengumpulan data), data processing (pengolahan data), verification (pembuktian), dan generalization (menarik kesimpulan/generalisasi).

\section{DAFTAR PUSTAKA}

Anni, Catharina Tri, dkk. 2006. Psikologi Belajar. Semarang: UNNES Press.

Arikunto, Suharsimi. 2009. Dasar-Dasar Evaluasi Pendidikan. Jakarta: Rineka Cipta.

2005. Manejemen Penelitian. Jakarta: Rineka Cipta.

2009. Penelitian Tindakan Kelas. Jakarta: Rineka Cipta.

------ 2010. Prosedur Penelitian Suatu Pendekatan Praktik. Jakarta: Rineka Cipta.

Direktorat Pembinaan Sekolah Menengah Atas. 2017. Model-model Pembelajaran. Jakarta: Kementerian Pendidikan dan Kebudayaan

Hadi, Sutrisno. 2004. Statistika Jilid 2. Yogyakarta: Andi.
Hamalik, Oemar. 2004. Psikologi Belajar Mengajar. Bandung: Sinar Baru Algensindo.

2003. Proses Belajar Mengajar. Jakarta: Bumi Aksara.

Kementerian Pendidikan dan Kebudayaan. 2017. Pendidikan Agama Katolik dan Budi Pekerti. Jakarta: Kementerian Pendidikan dan Kebudayaan

Mudjiono, Dimyati. 2006. Belajar dan Pembelajaran. Jakarta: Rineka Cipta.

Purwanto, M. Ngalim. 2004. Psikologi Pendidikan. Jakarta: Rosda.

Sanjaya, Wina. 2011. Strategi Pembelajaran Berorientasi Standar Proses Pendidikan. Jakarta: Praneda Media.

Slameto. 2010. Belajar dan Faktor yang Mempengaruhinya. Jakarta: Rineka Cipta.

Sugiyanto. 2010. Model-model Pembelajaran Inovatif. Surakarta: Yuma Pressindo.

Sugiyono. 2010. Metode Penelitian Pendidikan. Bandung: Alfabeta.

Suparman Kardi \& Muhamad Nur. 2000. Pengantar pada Pengajaran dan Pengelolaan Kelas. Surabaya: Surabaya University Press.

Trianto. 2007. Model-model Pembelajaran Inovatif Berorientasi Konstruktivistik. Jakarta: Prestasi Pustaka. 2010. Mendesain Model Pembelajaran Inovatif-Progesif. Jakarta: Kencana.

Uno, Hamzah B. 2011. Belajar dengan Pendekatan PAILKEM. Jakarta: PT Bumi Aksara.

Uno, Hamzah B. 2009. Model Pembelajaran Menciptakan Proses Belajar Mengajar yang Kreatif dan Efektif. Jakarta: Bumi Aksara.

https://ainamulyana.blogspot.com/2016/06/m odel-pembelajaran-discoverylearning.html

https://bacapikiran.com/pembelajarandiscovery-learning/

https://edutaka.blogspot.com/2015/03/modelpembelajaran-discovery-learning.html 